\title{
Algal wrack deposits and macroinfaunal arthropods on sandy beaches of the Chilean coast
}

\author{
Depósitos de algas varadas y artrópodos macroinfaunales en playas de arena \\ de la costa de Chile
}

EDUARDO JARAMILLO ${ }^{1 *}$, ROSARIO DE LA HUZ ${ }^{2}$, CRISTIAN DUARTE$^{1} \&$ HERALDO CONTRERAS $^{1}$

\author{
${ }^{1}$ Instituto de Zoología, Facultad de Ciencias, Universidad Austral de Chile, Valdivia, Chile \\ ${ }^{2}$ Departamento de Ecología y Biología Animal, Facultad de Ciencias, Universidad de Vigo, Vigo, España; \\ * e-mail for correspondence: ejaramillo@uach.cl
}

\begin{abstract}
Four Chilean sandy beaches were sampled during the summer of 2000 , to study the role of stranded algal wrack deposits on the population abundances of three detritus feeder species of the macroinfauna that inhabit the upper shore levels of that beaches: the talitrid amphipod Orchestoidea tuberculata Nicolet, the tylid isopod Tylos spinulosus Dana and the tenebrionid insect Phalerisida maculata Kulzer. The beaches were Apolillado (ca. $29^{\circ} \mathrm{S}$ ), Quidico (ca. $38^{\circ} \mathrm{S}$ ), Guabún and Mar Brava (ca. $42^{\circ} \mathrm{S}$ ). Replicated samples were collected with a plastic cylinder $(25 \mathrm{~cm}$ in diameter) from algal wrack deposits including the sediments beneath the wrack and nearby bare sand areas. Samples were collected at two beach levels, one closer to the sea with fresh deposits and other located on the upper beach with dry alga. Algal wrack deposits were mostly composed of the brown algae Macrocystis pyrifera (L.), Durvillaea antarctica (Chamisso) Hariot and Lessonia nigrescens Bory. O. tuberculata was found in the algal wrack deposits and bare sands collected from Apolillado, Quidico, Guabún and Mar Brava. On the other hand, T. spinulosus was just found at Apolillado, while $P$. maculata occurred in the sands beneath algal wrack deposits and bare sands collected from Apolillado, Quidico and Guabún. In general, the mean abundances of O. tuberculata, P. maculta and T. spinulosus were significantly higher in those samples collected from sands beneath algal wrack deposits; i.e., 56, 61 and 14 times higher (overall means) than in bare sands, respectively. It is concluded that stranded algal wrack deposits indeed promote an increase in population abundances of sandy beach detritus feeders, either because that deposits provide their main food source or shelter against variable environmental conditions (e.g., air temperature and humidity) during daylight hours. That might well explain the patchiness shown by these organisms, either across or along shore. This conclusion has important implications for sampling design of sandy beaches characterized by high inputs of algal wrack deposits.
\end{abstract}

Key words: algal wrack deposits, sandy beach arthropods, Chilean coast.

\section{RESUMEN}

Se muestrearon cuatro playas arenosas del litoral chileno durante el verano de 2000, para estudiar el rol de depósitos de algas varadas sobre las abundancias de las poblaciones de tres especies detritívoras de la macroinfauna que habita los niveles intermareales superiores de estas playas: el anfípodo talítrido Orchestoidea tuberculata Nicolet, el isópodo tílido Tylos spinulosus Dana y el insecto tenebriónido Phalerisidia maculata Kulzer. Las playas estudiadas fueron Apolillado (ca. 29 $\mathrm{S}$ ), Quidico (ca. $38^{\circ} \mathrm{S}$ ), Guabún y Mar Brava (ca. $\left.42^{\circ} \mathrm{S}\right)$. Se recolectaron muestras replicadas con un cilindro plástico $(25 \mathrm{~cm}$ de diámetro) de los depósitos de algas, incluyendo el sedimento situado por debajo de los mismos y de zonas de la playa próximas a los acúmulos de algas pero carentes de las mismas. Las muestras se recolectaron en dos niveles de la playa, uno más próximo a la orilla con acúmulos de algas frescas y otro en la zona superior de la playa con algas secas. Los depósitos de algas varadas estuvieron compuestos principalmente por las algas pardas Macrocystis pyrifera (L.), Durvillaea antarctica (Chamisso) Hariot y Lessonia nigrescens Bory. O. tuberculata fue encontrada en los depósitos de algas y zonas de la playa cercanas a los mismos y estudiados en Apolillado, Quidico, Guabún y Mar Brava. Por otro lado, T. spinulosus fue recolectada solo en Apolillado, mientras que $P$. maculata ocurrió en los depósitos de algas y zonas de la playa cercanas a los mismos y analizados en Apolillado, Quidico y Guabún. En general, las abundancias medias de las tres especies fueron significativamente más altas en aquellas muestras recolectadas de los depósitos de algas y sedimentos subyacentes; i.e., 56, 61 y 14 veces más altas (promedios totales) que en arenas sin restos de algas. Se 
concluye que las algas varadas sobre la superficie de la playa promueven un incremento de las abundancias poblacionales de los detritívoros de playas arenosas, ya sea porque representan la fuente principal de alimento para estos organismos o porque proveen de refugio, ante, por ejemplo, condiciones ambientales variables (e.g., temperatura, humedad) durante las horas del día. Lo anterior puede explicar la distribución en parches que presentan estos organismos, tanto a lo largo como a lo ancho del intermareal. Esta conclusión tiene implicaciones importantes para el diseño de muestreos en playas arenosas caracterizadas por un elevado aporte de depósitos de algas varadas sobre el intermareal.

Palabras clave: depósitos de algas varadas, artrópodos de playas arenosas, costa chilena.

\section{INTRODUCTION}

The intertidal zones of sandy beaches around the world are characterized by unconsolidated shifting sands; for this reason, these habitats are devoid of the large primary producers characteristically found on nearby rocky shores (Lewin \& Shaefer 1983, McLachlan 1983, Brown \& McLachlan 1990). Thus, the food supply for the often abundant macroinfauna of sandy beaches is primarily composed of phytoplankton and algal wrack deposits stranded on the beach face (Griffiths et al. 1983, Koop \& Lucas 1983, Colombini et al. 2000). Phytoplankton, distributed along the turbulent zone of the lower shore by wave mixing and swash dynamics, are consumed by suspension feeders such as anomuran crabs (different species of Emerita, Blepharipoda and Lepidopa) and bivalves (different species of Mesodesma, Donax, Amphidesma and Tivela, among others) (Hedgpeth 1957, Efford 1966, Ansell 1983, Brown \& McLachlan 1990). On the other hand, algal wrack deposits represent the main food resource for upper shore detritus feeders like talitrid amphipods (Orchestoidea, Talitrus and other genera), tylid and oniscoid isopods (genus Tylos and Alloniscus) and tenebrionid and staphylinid beetles (Phalerisida, Thinopinus, Cafius, Bledius and other genera) (Bowers 1964, Craig 1973, Duarte 1974, Kensley 1974, Hayes 1977, Koop \& Field 1980, Stenton-Dozey \& Griffiths 1983, Richards 1984, Inglis 1989, Marsden 1991a, 1991b, Brown \& Odendaal 1994, Colombini et al. 2000, Dugan et al. 2003).

The population abundance and zonation of the macroinfaunal detritus feeders inhabiting the upper shore levels of exposed sandy beaches have been shown to respond to spatial and temporal variability in the supply of drift macrophytes. For example, Koop \& Griffiths (1982) and Stenton-Dozey \& Griffiths (1983) found that not only abundance and biomass of the macroinfauna were concentrated around the drift line of algal wrack deposits, but also species richness on an exposed sandy beach of the west coast of South Africa. Marsden (1991a) found a significant association between algal debris and distribution and density of the talitrid amphipod Talorchestia quoyana (MilneEdwards) on a sandy beach of New Zealand. Moreover, this author found that the strength of that association was greater for freshly deposited algae than aged algal wrack deposits. Recently, Dugan et al. (2003) showed that in sandy beaches of California, subsidies of algal wrack deposits play a significant role in macroinfaunal community structure by increasing species richness and population abundance and thus, prey availability for shorebirds.

Three detritus feeder species inhabit the upper shore levels of Chilean sandy beaches: the talitrid amphipod Orchestoidea tuberculata Nicolet, the tylid isopod Tylos spinulosus Dana and the tenebrionid insect Phalerisida maculata Kulzer (Jaramillo 1987). While O. tuberculata and $P$. maculata have wider geographic ranges along the Chilean coast (about $22-42^{\circ}$ and 18 $42^{\circ} \mathrm{S}$, respectively) that of $T$. spinulosus is restricted to a narrower coastal range extending between 23 and $30^{\circ} \mathrm{S}$ approximately (Jaramillo 1987, 1994, Schmalfuss \& Vergara 2000). These detritus feeders are primarily active during the night when they leave the substrate and move over the beach surface (Jaramillo et al. 1980, 2000, 2003, Kennedy et al. 2000) to feed on algal wrack deposits stranded on the beach face during previous high tides; they bury again before or during dawn and remain beneath the sand surface or in sands located beneath algal wrack deposits during the day as do other talitrid amphipods, tylid isopods and tenebrionid insects elsewhere (e.g., Bowers 1964, Craig 1973, Kensley 1974, StentonDozey \& Griffiths 1983, Colombini et. al. 2000). 
Subtidal and nearshore beds of large brown macroalgae (Macrocystis pyrifera (L.), Lessonia nigrescens Bory and Durvillaea antarctica (Chamisso) Hariot) develop all along the latitudinal range occupied by $O$. tuberculata, T. spinulosus and $P$. maculata (e.g., Guiler 1959a, 1959b, Santelices 1981, Moreno et al. 1984, Vásquez et al. 1998); thus, accumulations of stranded algae on the beach face are a ubiquitous feature of Chilean sandy beaches. Although several studies investigating the community level and behavioural aspects of $O$. tuberculata, $T$. spinulosus and $P$. maculata have been conducted (Avellanal et al. 2000, Jaramillo 2001, Jaramillo et al. 2000, 2003), no attempt to evaluate relationships between the population abundances of $O$. tuberculata, $P$. maculata and $T$. spinulosus and algal wrack deposits has been made. So far, the only study dealing with this question is that of Duarte (1974) who estimated the macroalgal consumption of $O$. tuberculata on a sandy beach of south central Chile. He concluded that the high consumption of adult amphipods (24.8 mg of dry algae per day) could account for the rapid decay of stranded algae on sandy beaches of southern Chile.

The present study aims to describe the effect of algal wrack deposits on the spatial distribution, composition and population abundance of upper shore detritus feeders at four sandy beaches located across a broad latitudinal range on the Chilean coast. Since some studies have shown that taxonomic composition of the detritus feeder guild of algal wrack deposits can be related to the age of the stranded algae (Griffiths \& Stenton-Dozey 1981, Inglis 1989, Marsden 1991a, Colombini et al. 2000), we analyzed the population abundances of $O$. tuberculata, P. maculata and $T$. spinulosus associated with dry old algal wrack deposits located further up the drift line and with fresh macroalgae stranded lower down the beach face during the daytime at low tide. Since population abundance data of buried animals form the basis of the across shore zonation patterns described to date for the sandy beach macroinfauna (see McLachlan \& Jaramillo 1995 for a review), we use the data of this study to consider the implications of distribution and amount of algal wrack deposits on our current understanding of zonation patterns on exposed sandy beaches.

\section{MATERIAL AND METHODS}

\section{Study sites}

The four sandy beaches studied were Apolillado (29 $10^{\circ}$ S, $\left.71^{\circ} 29^{\prime} \mathrm{W}\right)$, Quidico

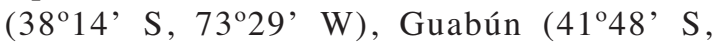
$74^{\circ} 01^{\prime} \mathrm{W}$ ) and Mar Brava (41 ${ }^{\circ} 54^{\prime} \mathrm{S}, 73^{\circ} 59^{\prime}$ $\mathrm{W})$; their approximate locations are shown in Fig. 1. Apolillado is about $1000 \mathrm{~km}$ north of Quidico and near 1,400 km north of Guabún and Mar Brava which are nearly $5 \mathrm{~km}$ apart each other.

\section{Field samplings}

Samples were collected during the spring low tides of late January (Guabún and Mar Brava) and early February 2000 (Apolillado and Quidico) from two bands of algal wrack deposits: an upper band, composed of dry algae desiccated by exposure to air and sun and stranded above the current high tide line or drift line, and a lower band with wet fresh algae deposited on the beach during the last high tide and located at the current drift line. While the upper bands of algal wrack deposits of Apolillado and Quidico were located on the retention zone, those from Guabún and Mar Brava were located on the dry zone of the beach (Table 1). Thus, the upper bands of algal wrack deposits in Apolillado and Quidico were located on wetter sands, than those studied at Guabún and Mar Brava. Lower bands of wracks from all beaches were all located on the retention zone (Table 1). The height above the low water line (LWL hereafter) of each band was measured using the Emery's profiling technique, i.e. eye-leveling of wave crest and the horizon from the low tide level (Emery 1961); also, the distance between bands. The sampling points were randomly chosen along the upper and lower band of algal wrack deposits. The along shore distance of the sampling area was 60-80 m. Twelve core samples were collected from each band during low tide with a plastic cylinder $25 \mathrm{~cm}$ in diameter $\left(0.05 \mathrm{~m}^{2}\right)$ buried to a depth of $30 \mathrm{~cm}$. At each band, six samples were collected from areas with algal wracks (thus, samples included these wracks and the sediments underneath); another six samples were collected from nearby bare sand areas $(2 \mathrm{~m}$ apart from sampling 
points of algal wrack deposits). The samples collected were washed through a 1000 micron sieve; the macroinfauna obtained were stored in $5 \%$ seawater-formalin until sorting, while algal wrack deposits collected were kept in closed plastic bags until determinations of fresh weight soon after. Later on, those samples were dried for two days $\left(60{ }^{\circ} \mathrm{C}\right)$. Water contents of algal wrack deposits were determined by calculations of weight differences.

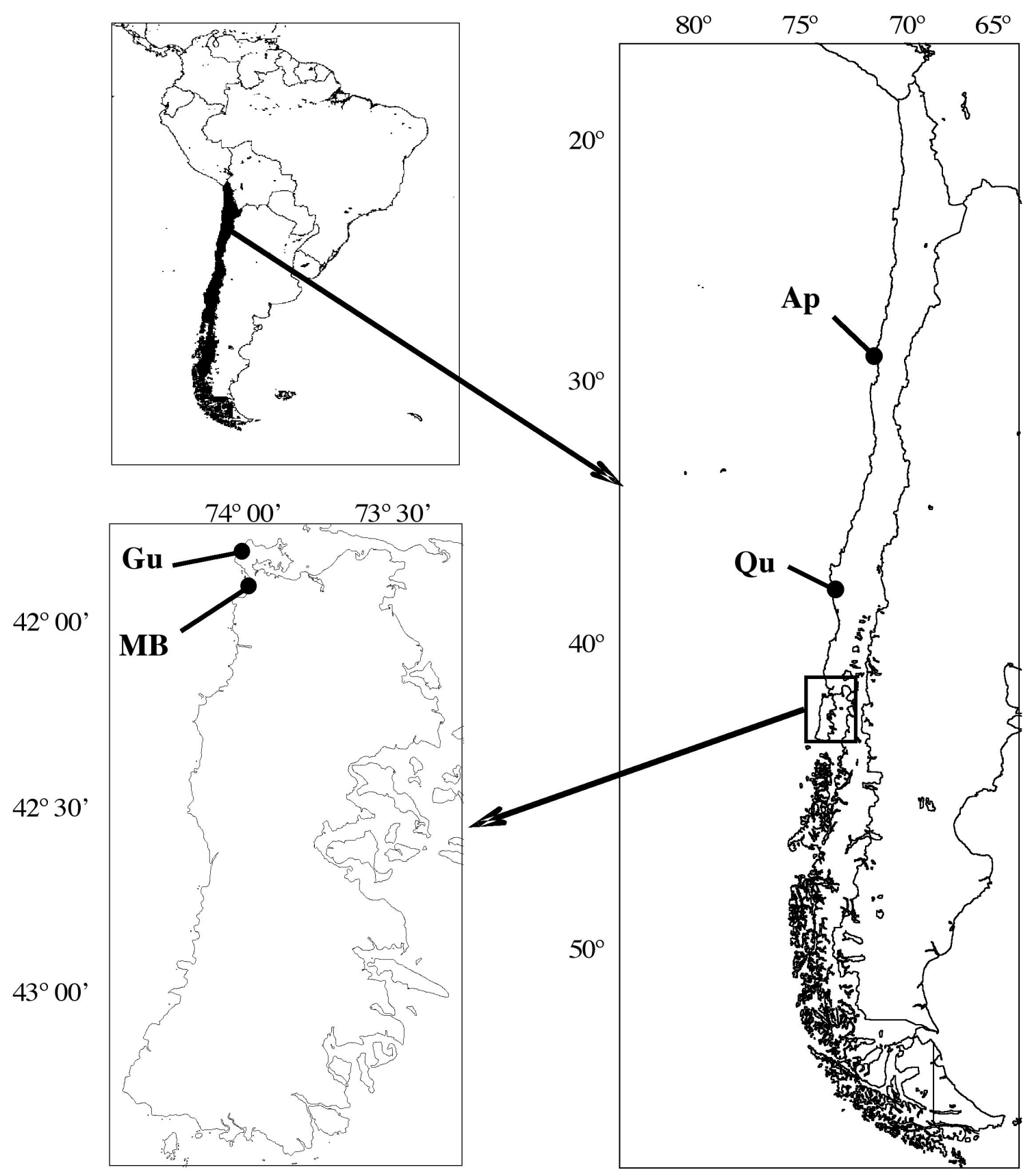

Fig. 1: Location of Apolillado (Ap), Quidico (Qu), Guabún (Gu) and Mar Brava (MB) on the Chilean coast.

Localización de Apolillado (Ap), Quidico (Qu), Guabún (Gu) y Mar Brava (MB) en la costa chilena. 
TABLE 1

Values of Dean's parameter and distance from the drift line (present high tide) to the low water line (LWL) at each beach, height above the low water line of the upper and lower band of algal wrack deposits and distance between bands (RT, retention zone; DRY, dry zone)

Valores del parámetro de Dean y distancia desde el nivel de marea alta a la línea de marea baja (LWL) en cada playa, altura sobre el nivel de marea baja de las bandas superior e inferior de los depósitos de algas y distancias entre las bandas (RT, zona de retención; DRY, zona de arena seca)

\begin{tabular}{|c|c|c|c|c|c|c|}
\hline \multirow[t]{2}{*}{ Beach } & \multirow{2}{*}{$\begin{array}{l}\text { Dean's } \\
\text { parameter }\end{array}$} & \multirow{2}{*}{$\begin{array}{c}\text { Distance from } \\
\text { drift line to LWL (m) }\end{array}$} & \multicolumn{3}{|c|}{ Height above the low water line (LWL) } & \multirow{2}{*}{$\begin{array}{c}\text { Distance between } \\
\text { bands }(\mathrm{m})\end{array}$} \\
\hline & & & Upper band $(\mathrm{cm})$ & Lower band $(\mathrm{cm})$ & Difference $(\mathrm{cm})$ & \\
\hline Apolillado & 4.1 & 53 & $288(\mathrm{RT})$ & $247(\mathrm{RT})$ & 21 & 7 \\
\hline Quidico & 4.7 & 34 & $172(\mathrm{RT})$ & $167(\mathrm{RT})$ & 5 & 16 \\
\hline Guabún & 2.2 & 22 & $338(\mathrm{DRY})$ & $266(\mathrm{RT})$ & 72 & 10 \\
\hline Mar Brava & 6.2 & 99 & 255 (DRY) & $189(\mathrm{RT})$ & 66 & 18 \\
\hline
\end{tabular}

Sediment samples $(n=3)$ were collected from the LWL of each beach to be used in estimations of Dean's parameter (see below). Wave height was estimated by measuring the height of breaking waves $(n=15)$ with graduated poles against the horizon, and adding the result to the height difference between the location of the observer and the lowest point where the backwash met the next incoming swash bore. The wave period (measured with a stop watch) was the time interval between breaking waves.

\section{Analytical procedures}

The grain size distributions of sands were analyzed using a settling tube (Emery 1938). Mean grain size was calculated according to the moments computational method (SewardThompson \& Hails 1973). Mean grain size of sands from the LWL was used to estimate sand fall velocity according to the method described by Gibbs et al. (1971). From estimated mean wave height, wave period and sand fall velocity of sands, Dean's parameter $(\Omega)$ (Short \& Wright 1983) was calculated to estimate morphodynamic type of each beach (Short \& Wright 1983).

Fresh weight and water content of algal wrack deposits collected at the upper and lower band of stranded algae were compared with one way ANOVA on log and arcsin transformed data, respectively (Sokal \& Rohlf 1995). The effects of algal wrack deposits and beach levels (i.e. upper vs. lower bands of wracks) on the population abundances of Orchestoidea tuberculata, Phalerisida maculata and Tylos spinulosus were examined with two way ANOVA on $\log$ abundance +1 (Sokal \& Rohlf 1995). The transformation of data allowed to fulfill the assumptions of both analyses.

\section{RESULTS}

\section{Beach types and algal wrack deposits}

The beaches of Apolillado, Quidico and Guabún were intermediate types (sensu Short \& Wright 1983) with Dean's of 4.1, 4.7 and 2.2, respectively, while Mar Brava was a dissipative beach $($ Dean $=6.2)($ Table 1$)$. The width of the intertidal zone (i.e. distance from the drift line to the LWL) was lower at the beaches of Guabún and Quidico (22 and 34 m, respectively) and higher at Mar Brava (99 m) and Apolillado (53 m) (Table 1).

The upper band of algal wrack deposits was higher on the beach face at Apolillado and Guabún (288 and $338 \mathrm{~cm}$ above the LWL, respectively). The lowest difference between the height above the LWL of the upper and lower band of algal wrack deposits occurred at Quidico $(5 \mathrm{~cm})$, while the highest differences were found at Guabún and Mar Brava (72 and $66 \mathrm{~cm}$, respectively) (Table 1). The lowest distances between both bands were measured at Apolillado and Guabún (7 and $10 \mathrm{~m}$, 
respectively), while that measured at Quidico and Mar Brava were similar (16 and $18 \mathrm{~m}$ ) (Table 1).

Algal wrack deposits collected at the upper and lower band of Apolillado and Mar Brava were composed of Macrocystis pyrifera, while that of Quidico were represented by Lessonia nigrescens. Dry rests of Durvillaea antarctica made up the algal wrack deposits collected at the upper band of Guabún, while rests of Macrocystis pyrifera dominated at the lower band of the same beach (Table 2). The mean weight of algal wrack deposits per unit area $\left(0.05 \mathrm{~m}^{2}\right)$ was similar at the upper and lower band of stranded algae at Guabún; on the other hand, the mean weight of algal wrack deposits at Apolillado, Quidico and Mar Brava, was nearly twice at the lower band (Table 2). However, significant differences between weights of algal wrack deposits per unit area at both bands were only found for Apolillado (Table 2). Mean water contents of stranded algae of the lower band (mean ranges $=53.9$ $83.0 \%$ ) were significantly higher than those calculated for the upper band of each beach $($ mean ranges $=18.9-22.9 \%)($ Table 2$)$.

\section{The macroinfaunal arthropods}

The amphipod Orchestoidea tuberculata was found in algal wrack deposits and bare sands collected from Apolillado, Quidico, Guabún and Mar Brava (Fig. 2). Mean population abundances of this amphipod were significantly higher in the lower band (sands underneath algal wrack deposits and bare sands included) as compared to the upper band at all beaches (1,320 versus $780,16,305$ versus 18 and 14,930 versus 560 ind $\mathrm{m}^{-2}$ for Apolillado, Guabún and Mar Brava, respectively) but Quidico, where no significant differences were found (Table 3, Fig. 2). The mean population abundances of $O$. tuberculata, were significantly higher in algal wrack deposits (upper and lower bands included) as compared to that in bare sands $(2,010$ versus $90 ; 2,508$ versus $17 ; 15,221$ versus 1,112 and 15,073 versus 417 ind $\mathrm{m}^{-2}$ for Apolillado, Quidico, Guabún and Mar Brava, respectively, Fig. 2). In Guabún and Mar Brava, the abundances of $O$. tuberculata was influenced by the interaction between beach level (i.e., upper and lower bands) and the presence of algal wrack deposits (Fig. 2 and Table 3).

\section{The tenebrionid insect}

Phalerisida maculata occurred in algal wrack deposits and bare sands studied in Apolillado, Quidico and Guabún (Fig. 3). Mean population abundances of this beetle did not differ significantly when beach levels (sands underneath algal wrack deposits and bare sands included) were compared at Apolillado (Table 4, Fig. 3). On the other hand, mean population abundances of $P$. maculata were significantly higher at the upper beach levels of Quidico (sands underneath algal wrack deposits and bare sands included) (Table 4, Fig. 3). The mean population abundances of this species,

TABLE 2

Dominant species of macroalgae, fresh weight and water content of algal wrack deposits at the upper and lower band of each beach. The values of weight and water content are means $(n=6)$ with standard deviations in parentheses

Especies dominantes de macroalgas, peso fresco y contenido de agua en las algas de la banda superior e inferior de cada playa. Los valores de peso y contenidos de agua son promedios $(n=6)$ con desviación estándar en paréntesis

\begin{tabular}{|c|c|c|c|c|c|c|c|c|}
\hline \multirow[t]{2}{*}{ Beach } & \multicolumn{2}{|c|}{ Macroalgae at the: } & \multicolumn{2}{|c|}{ Fresh weight $(\mathrm{g})$ at the: } & \multirow[t]{2}{*}{ ANOVA statistics } & \multicolumn{2}{|c|}{ Water content (\%) at the: } & \multirow[t]{2}{*}{ ANOVA statistics } \\
\hline & Upper band & Lower band & Upper band & Lower band & & Upper band & Lower band & \\
\hline Apolillado & M. pyrifera & M. pyrifera & $368.33(119.7)$ & $805.8(300.2)$ & $\mathrm{F}_{1,10}=14.41, \mathrm{P}<0.01$ & $22.9(6.0)$ & $80.8(3.4)$ & $\mathrm{F}_{1,10}=425.09, \mathrm{P}<0.01$ \\
\hline Quidico & L. nigrescens & L. nigrescens & $393.3(230.0)$ & $876.7(512.2)$ & $\mathrm{F}_{1,10}=3.31, \mathrm{P}=0.09$ & $18.9(2.5)$ & $53.9(3.5)$ & $\mathrm{F}_{1,10}=393.70, \mathrm{P}<0.01$ \\
\hline Guabún & D. antarctica & M. pyrifera & $545.8(373.7)$ & $551.7(256.9)$ & $\mathrm{F}_{1,10}=0.17, \mathrm{P}=0.69$ & $19.6(1.7)$ & $83.0(3.7)$ & $\mathrm{F}_{1,10}=1493.76, \mathrm{P}<0.01$ \\
\hline Mar Brava & M. pyrifera & M. pyrifera & $544.2(289.3)$ & $903.3(293.4)$ & $\mathrm{F}_{1,10}=4.18, \mathrm{P}=0.07$ & $19.6(0.9)$ & $80.2(3.6)$ & $\mathrm{F}_{1,10}=1582.97, \mathrm{P}<0.01$ \\
\hline
\end{tabular}


were significantly higher in algal wrack deposits (upper and lower bands included) as compared to that in bare sands (417 versus 10 and 13 versus 2 ind $\mathrm{m}^{-2}$ for Apolillado and Quidico, respectively) (Fig. 3, Table 4). In bare sands of Guabún, beetles were collected just from one replicate; thus, no statistical analyses were carried out for this beach. Nevertheless, it can be seen from Fig. 3 that the highest abundance of $P$. maculata at this beach occurred underneath algal wrack deposits of the upper beach sampled.

\section{O. tuberculata}
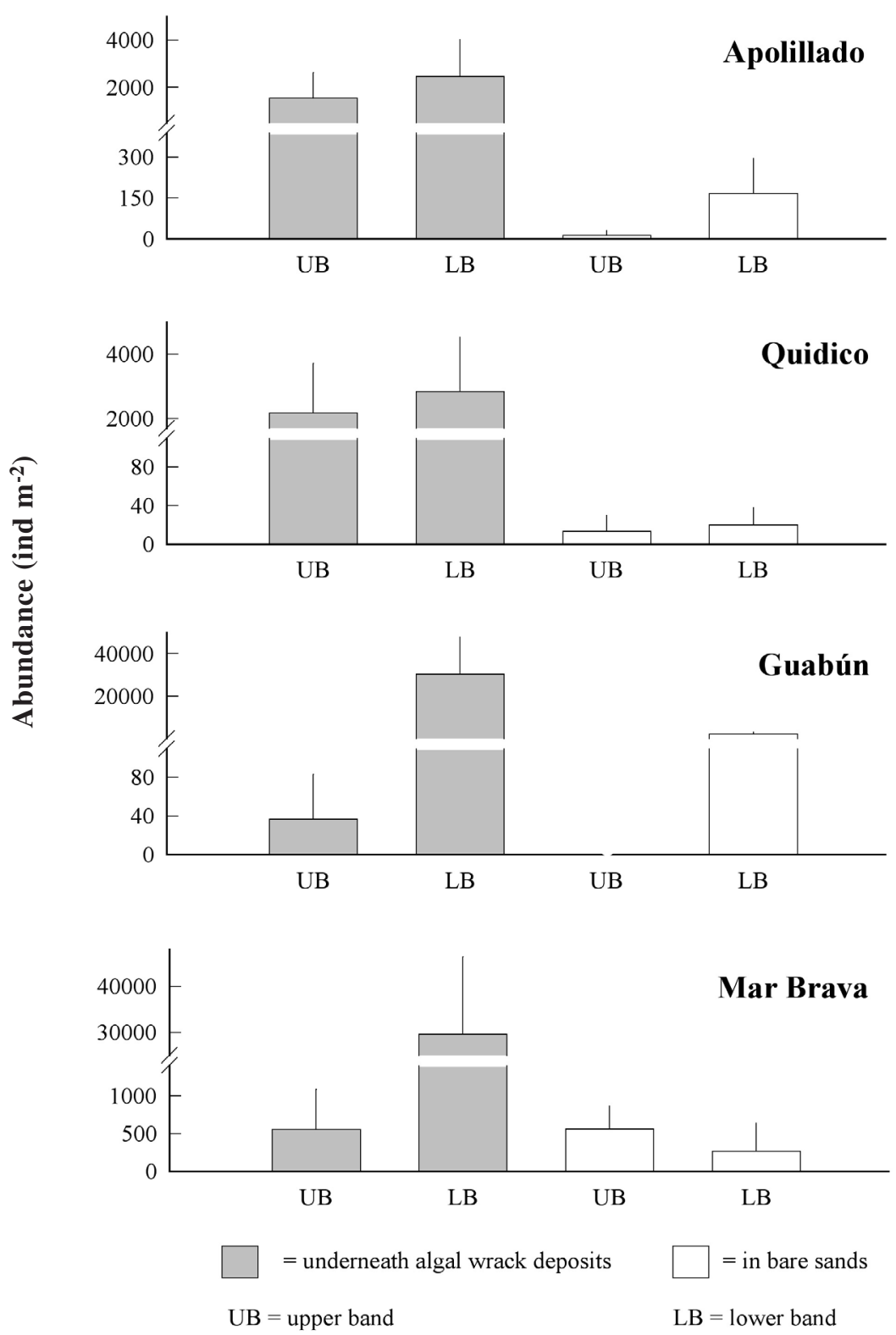

Fig. 2: Mean abundances of Orchestoidea tuberculata collected from algal wrack deposits plus sands underneath (see Material and Methods) and nearby bare sand areas at the study sites. The values are means plus one standard deviation.

Abundancias promedio de Orchestoidea tuberculata colectada en depósitos de algas varadas y arena subyacente (ver Materiales y Métodos) y en áreas cercanas en los sitios de estudio. Los valores son promedios más una desviación estándar. 


\section{TABLE 3}

Results of the two way ANOVA carried out to test for differences in population abundances of Orchestoidea tuberculata at the Apolillado, Quidico, Guabún and Mar Brava beaches (see Material and Methods)

Resultados de los ANDEVA de dos vías realizados para evaluar diferencias en la abundancia poblacional de Orchestoidea tuberculata en las playas de Apolillado, Quidico, Guabún y Mar Brava (ver Materiales y Métodos)

\begin{tabular}{|c|c|c|c|c|}
\hline Source of variaton & Degrees of freedom & Mean square & F-ratio & P-value \\
\hline \multicolumn{5}{|l|}{ Apolillado } \\
\hline Beach level & 1 & 1.37 & 12.73 & $<0.01$ \\
\hline Algal wracks & 1 & 11.33 & 105.25 & $<0.01$ \\
\hline Interaction & 1 & 0.24 & 2.25 & 0.15 \\
\hline Residual & 20 & 0.11 & & \\
\hline Total & 23 & & & \\
\hline \multicolumn{5}{|l|}{ Quidico } \\
\hline Beach level & 1 & 0.02 & 0.10 & 0.75 \\
\hline Algal wracks & 1 & 17.96 & 119.12 & $<0.01$ \\
\hline Interaction & 1 & 0.01 & 0.03 & 0.86 \\
\hline Residual & 20 & 0.15 & & \\
\hline Total & 23 & & & \\
\hline \multicolumn{5}{|l|}{ Guabún } \\
\hline Beach level & 1 & 34.60 & 684.6 & $<0.01$ \\
\hline Algal wracks & 1 & 3.23 & 64.03 & $<0.01$ \\
\hline Interaction & 1 & 0.93 & 18.32 & $<0.01$ \\
\hline Residual & 20 & 0.05 & & \\
\hline Total & 23 & & & \\
\hline \multicolumn{5}{|l|}{ Mar Brava } \\
\hline Beach level & 1 & 3.58 & 13.59 & $<0.01$ \\
\hline Algal wracks & 1 & 5.98 & 22.71 & $<0.01$ \\
\hline Interaction & 1 & 8.12 & 30.84 & $<0.01$ \\
\hline Residual & 20 & 0.26 & & \\
\hline Total & 23 & & & \\
\hline
\end{tabular}

The tylid isopod Tylos spinulosus was found only at the algal wrack deposits and bare sands of Apolillado (Fig. 4). Mean population abundances of this isopod did not differ significantly when beach levels (sands underneath algal wrack deposits and bare sands included) were compared (Table 5, Fig. 3). The mean population abundances of $T$. spinulosus, were significantly higher in algal wrack deposits (upper and lower bands included) (1,283 versus 95 ind $\mathrm{m}^{-2}$ ) (Table 5, Fig. 5).

\section{DISCUSSION}

Population abundances of a variety of consumers can be potentially determined by food availability (e.g., Hunter \& Price 1992,
Polis \& Hurd 1995, 1996, Menge et al. 1999), especially in habitats where food sources are of allocthonous origin, such as sandy beaches. The results of this study provide new evidence on this: in most of the samples collected from algal wrack deposits (either at the upper or lower band of stranded algae), the mean population abundances of $O$. tuberculata, $P$. maculata and $T$. spinulosus were significantly higher than those found in bare sand areas located nearby that deposits. These results are similar to that found by Dugan et al. (2000, 2003) for sandy beaches of California, by Koop \& Field (1980), Griffiths \& Stenton-Dozey (1981), Griffiths et al. (1983) and StentonDozey \& Griffiths (1983) for the sand coast of South Africa, and by McLachlan (1985) for sandy beaches of Australia. 
P. maculata
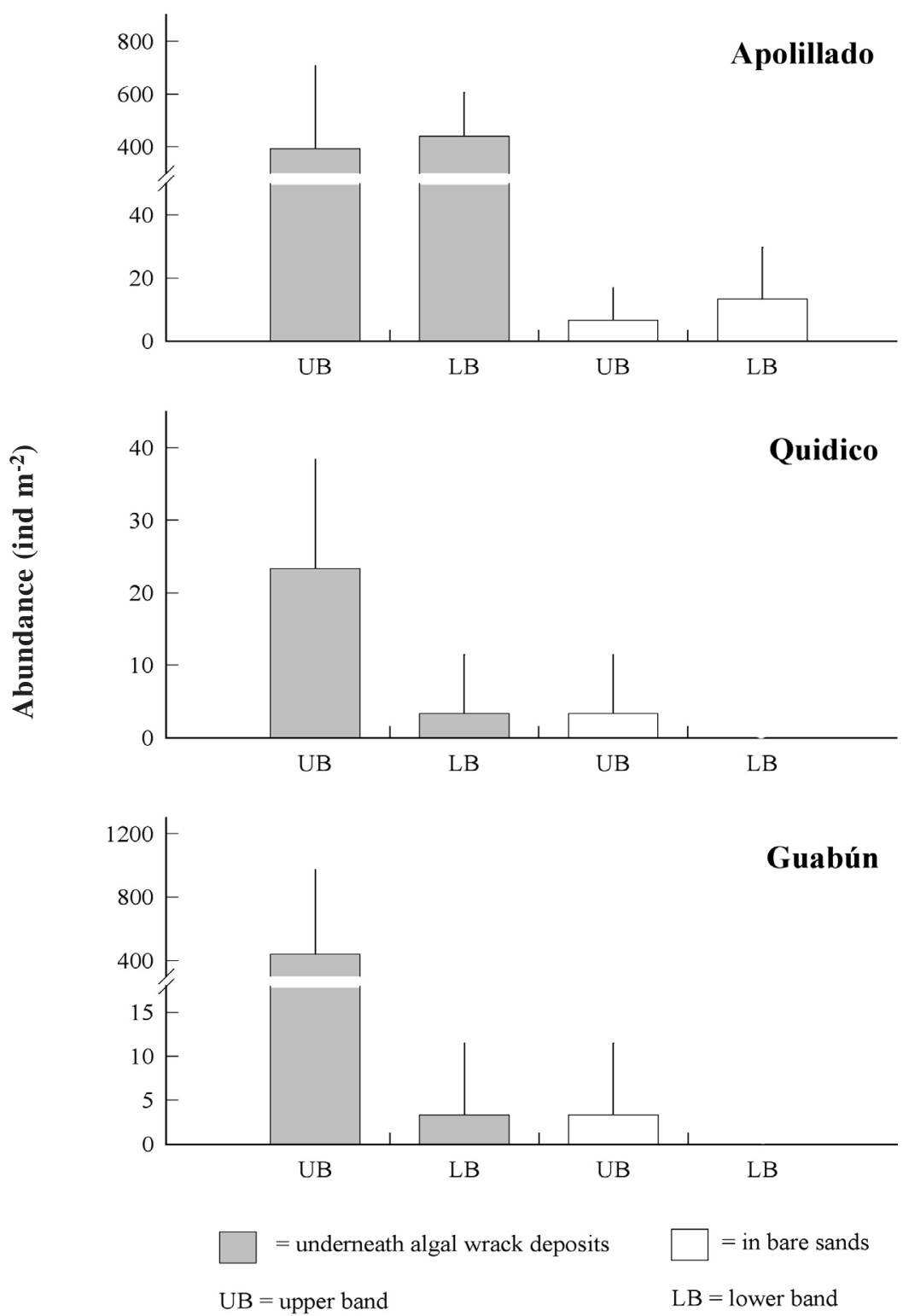

Fig. 3: Mean abundances of Phalerisida maculata collected from algal wrack deposits plus sands underneath (see Material and Methods) and nearby bare sand areas at the study sites. The values are means plus one standard deviation.

Abundancias promedio de Phalerisidia maculata colectada en depósitos de algas varadas y arena subyacente (ver Materiales y Métodos) y en áreas cercanas en los sitios de estudio. Los valores son promedios más una desviación estándar. 


\section{TABLE 4}

Results of the two way ANOVA carried out to test for differences in population abundances of Phalerisida maculata at the Apolillado and Quidico beaches (see Material and Methods)

Resultados de los ANDEVA de dos vías realizados para evaluar diferencias en la abundancia poblacional de Phalerisida maculata en las playas Apolillado y Quidico (ver Materiales y Métodos)

\begin{tabular}{|c|c|c|c|c|}
\hline Source of variaton & Degrees of freedom & Mean square & F-ratio & P-value \\
\hline \multicolumn{5}{|l|}{ Apolillado } \\
\hline Beach level & 1 & 0.21 & 1.75 & 0.20 \\
\hline Algal wracks & 1 & 6.63 & 56.52 & $<0.01$ \\
\hline Interaction & 1 & 0.07 & 0.57 & 0.46 \\
\hline Residual & 20 & 0.12 & & \\
\hline Total & 23 & & & \\
\hline \multicolumn{5}{|l|}{ Quidico } \\
\hline Beach level & 1 & 0.10 & 5.26 & 0.03 \\
\hline Algal wracks & 1 & 0.10 & 5.26 & 0.03 \\
\hline Interaction & 1 & 0.04 & 1.98 & 0.18 \\
\hline Residual & 20 & 0.02 & & \\
\hline Total & 23 & & & \\
\hline
\end{tabular}

\section{T. spinulosus}

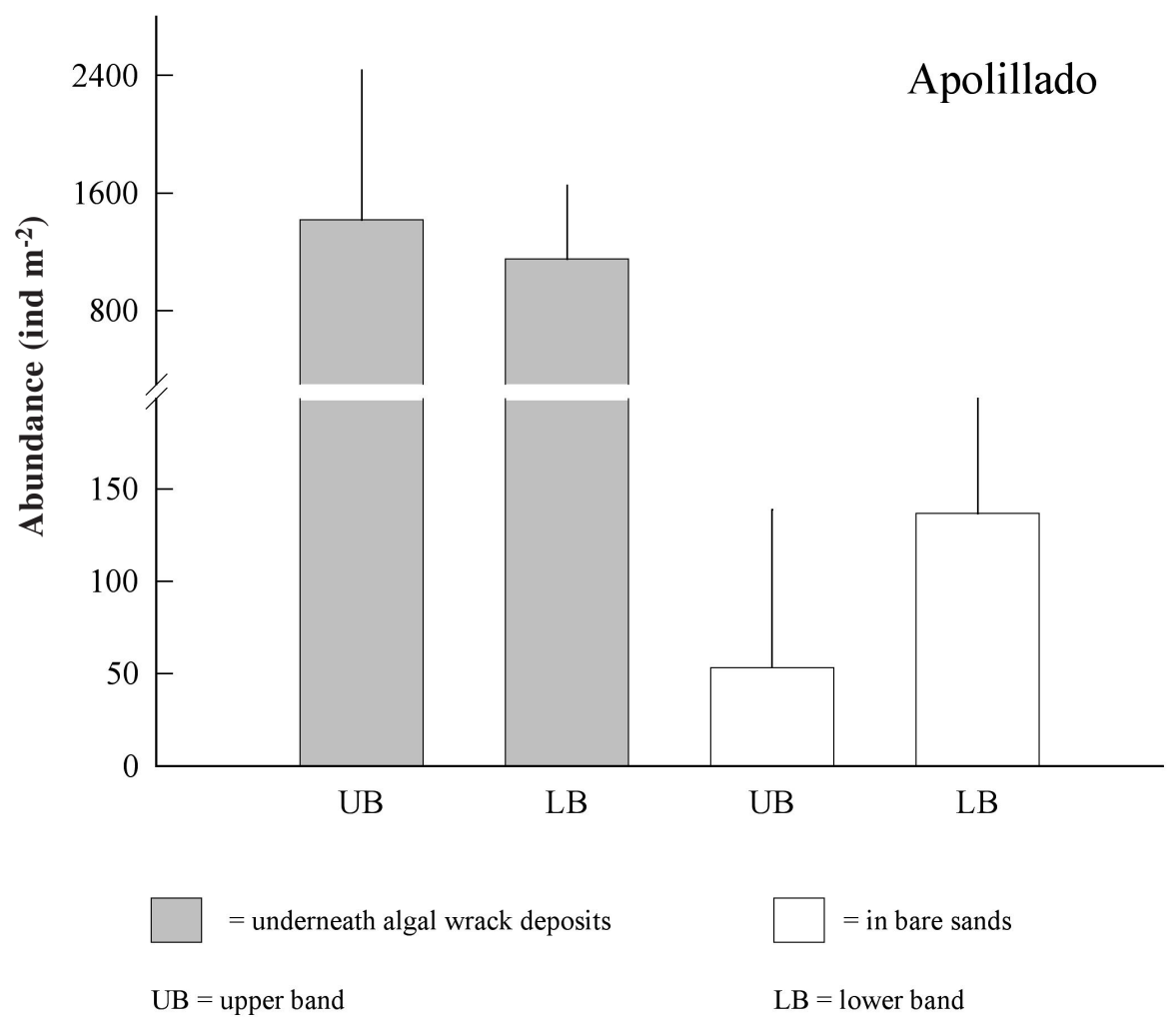

Fig. 4: Mean abundances of Tylos spinulosus collected from algal wrack deposits plus sands underneath (see Material and Methods) and nearby bare sand areas at El Apolillado. The values are means plus one standard deviation.

Abundancias promedio de Tylos spinulosus en depósitos de algas varadas y arena subyacente (ver Materiales y Métodos) y en áreas cercanas sin algas varadas en Apolillado. Los valores son promedios más una desviación estándar. 
TABLE 5

Results of the two way ANOVA carried out to test for differences in population abundances of Tylos spinulosus at the Apolillado beach (see Material and Methods)

Resultados de los ANDEVA de dos vías realizados para evaluar diferencias en la abundancia poblacional de Tylos spinulosus en la playa de Apolillado (ver Materiales y Métodos)

\begin{tabular}{lcrrr}
\hline Source of variaton & Degrees of freedom & Mean square & F-ratio & P-value \\
\hline Apolillado & & & & 0.12 \\
Beach level & 1 & 0.64 & 28.39 & $<0.01$ \\
Algal wracks & 1 & 6.93 & 0.50 & 0.49 \\
Interaction & 1 & 0.12 & & \\
Residual & 20 & 0.24 & & \\
Total & 23 & & & \\
\hline
\end{tabular}

As suggested by Koop \& Field (1980), the supralittoral macroinfauna is rather affected by availability of food (such as algal wrack deposits) than by physical characteristics of the beach. This assertion has been recently demonstrated by Dugan et al. (2003) in sandy beaches of California by showing that algal wrack associated macroinfauna was significantly enhanced by cover of that detritus, while physical features of beaches such as sediment size, beach slope and beach type, did not explain significantly the variability of that macroinfauna. The last authors also found that beaches groomed regularly of algal wrack deposits harbored a less diverse and abundant macroinfauna than ungroomed beaches. Thus, the presence of algal wrack deposits, might well explain lack of relationships between population abundances of upper beach organisms such as talitrid amphipods and beach morphodynamics (e.g., Jaramillo \& McLachlan 1993, Gómez \& Defeo 1999, Contreras et al. 2003) or that between abundances of the whole macroinfauna and beach morphodynamics on sandy beaches where some of these detritus feeders (e.g., talitrids) make up most of the abundance figures (e.g., Jaramillo \& McLachlan 1993, Jaramillo et al. 2001). Since upper beach arthropods usually live buried beyond the intertidal zone affected by the swashes of incoming waves, location and abundance of algal wrack deposits are probably more important in influencing population abundances of talitrid amphipods, tylid isopods and tenebrionid insects than variability in swash features associated to each morphodynamic beach type (see McArdle \& McLachlan 1991, 1992).
The talitrid amphipod O. tuberculata was the most abundant of the three species found at the algal wrack deposits of the beaches studied at the Chilean coast; this is similar to the findings of other authors which had found that talitrid amphipods usually dominate in sands located beneath the algal wrack deposits and in bare sands of the upper shore levels of exposed sandy beaches (MacIntyre 1963, Koop \& Griffiths 1982, Griffiths et al. 1983, StentonDozey \& Griffiths 1983). Several authors have also noticed that talitrid amphipods are considered primary macroinfaunal colonizers of newly (fresh) algal wrack deposits stranded on sandy beaches (Griffiths \& Stenton-Dozey 1981, Inglis 1989, Marsden 1991a, Colombini et al. 2000). Our results generally agree with the above, since in general, the highest abundances of $O$. tuberculata occurred at or underneath fresh stranded macroalgae suggesting food preference. On the other hand, the tenebrionid insect $P$. maculata showed the opposite pattern (more abundant on aged dry algal wrack deposits). Assuming that the higher occurrence of $O$. tuberculata and $P$. maculata at or underneath fresh and dry stranded macroalgae respectively, is actually the outcome of food preference (and not preference for example for microclimatic conditions), it can be hypothesized that opposite patterns are the result of differences in metabolic requirement of each species (Renaud et al. 1990, Colombini et al. 2000, Penning et al. 2000).

It is also possible that the lower abundances of $O$. tuberculata underneath the algal wrack deposits of the upper bands of Guabún and Mar 
Brava were related to the water content of sediments. While the upper and lower bands of algal wrack deposits of Apolillado and Quidico were located on the retention zone, the upper bands of Guabún and Mar Brava were located on the dry zone of the beach. Unpublished data (EJ) show that during summer, the ranges in water content of sands of the dry zone of Guabún and Mar Brava vary nearly 1-3\% while in the retention zone that variability is close to $5-18 \%$. Since mortality of $O$. tuberculata is close to $100 \%$ in experimental sands with water contents close to $3 \%$ (Jaramillo 1987), it can be hypothesized that the lower abundance of this amphipod in the upper bands of algal wrack deposits was due to the lower content of interstitial waters in sands located at the dry zone. Moreover, the height differences between bands were higher at Guabún and Mar Brava (72 and $66 \mathrm{~cm}$, respectively) as compared to Apolillado and Quidico (21 and $5 \mathrm{~cm}$, respectively), differences which probably also convey differences in water content of sands and further support the above hypothesis. Thus, the distribution and population abundances of $O$. tuberculata may be the result of several combined factors, such as water content of sands and the presence of algal wrack deposits. This is would explain the results of the two way ANOVA: i.e., the population abundances of $O$. tuberculata were affected by the interaction between beach levels and presence of algal wrack deposits at the beaches of Guabún and Mar Brava (see Table 3).

The talitrid amphipod $O$. tuberculata and the tenebrionid insect $P$. maculata were collected all along the latitudinal range studied; however, P. maculata was not found at Mar Brava. On the other hand, T. spinulosus was just found at the beach located further north (Apolillado). Earlier explanations of the along coast variability in taxonomic composition of the upper beach assemblage of the Chilean coast, included hypothesis related to latitudinal variability in environmental factors (e.g., air temperature and water content of sediments) and possible biological interactions (Jaramillo 1987). However, there is no present evidence to support hypotheses related to environmental variability along the Chilean coast, and it was not until recently that results of laboratory experiments demonstrated biological interactions among these species: while $P$. maculata affected negatively the survival of $O$. tuberculata, this amphipod affected negatively the survival of $T$. spinulosus (Jaramillo et al. 2003). Thus, these sorts of interactions were used to explain the partition in space and time of the locomotor activity of these detritus feeders over the beach surface (Jaramillo et al. 2003). Similarly, the negative interactions found between $O$. tuberculata and P. maculata may be used to explain the higher population abundances of this amphipod in Mar Brava where $P$. maculata was absent. Notwithstanding, this explanation must be taken with caution since the results of this study, come from snapshot samplings; in other words, we are not sure if during some times of the year the insect is present at that beach.

In conclusion, the results of this study suggest that the population abundances of upper shore arthropods of sandy beaches located along the Chilean coast, can be affected by algal wrack deposits. The distribution of algal wrack may also explain along shore patchiness and temporal variability in the zonation of that macroinfauna. As shown by Bowers (1964) and Craig (1970), the zone where the talitrid amphipod Orchestoidea corniculata Stout and the staphylinid beetle Thinopinus pictus Leconte burrow in the upper shore of Californian beaches, moves up and down following the lunar cycle, as do the stranded algal wrack deposits. Similarly, Colombini et al. (2000), found that the sandy beach macroinfauna of a Somalian beach (Indian Ocean) changed its zonation according the location of algal wrack deposits changed throughout time. Thus, future studies aimed to understand community organization of sandy beaches should consider that input and cover of stranded algal wrack deposits may be more important for some taxa than physical factors operating on these coastal habitats (i.e., beach morphodynamics) (Dugan et al. 2003), which do not necessarily affect directly the upper shore macroinfauna represented by semiterrestrial animals which usually live buried at or above the drift line.

Our results have profound implications for sampling design for sandy beaches; especially when studies of across shore zonation of the macroinfauna are the primary aims. The intertidal zonation of the sand beach macroinfauna is a well known pattern around 
the world (see review by McLachlan \& Jaramillo 1995). Talitrid amphipods, tylid isopods, and tenebrionid insects are characteristic of the upper shore levels centred around the drift line, cirolanid isopods are usually the most typical organisms in the mid shore levels, while anomuran crabs (Emerita spp.), oedicerotid and phoxocephalid amphipods, and bivalves (Mesodesma and Donax spp. among others) dominate on the lower shore levels (e.g., Dahl 1952, Jaramillo 1994, McLachlan \& Jaramillo 1995). These zonation patterns originate from population abundance data of buried organisms (see McLachlan \& Jaramillo 1995 for a review), with causation primarily related to gradients of physical factors across the intertidal, including temperature, water content, compactness and grain size of sands (Salvat 1964, Rafaelli et al. 1991, Jaramillo \& Fuentealba 1993, Jaramillo et al. 1993, McLachlan \& Jaramillo 1995) but see e.g. Croker \& Hatfield (1980) which showed that biological interactions related to the use of the intertidal space cause differential zonation of related species of haustoriid amphipods on the sand coast of eastern United States). Based upon the results of this study, allocation of sample units across and along shore, should considerer that algal wrack deposits affect the distribution, population abundances of detritus feeder arthropods, and consequently the whole community structure and the zonation patterns of the upper shore macroinfauna. Up to now, many sandy beach ecologists seem to have avoided sampling in areas of beaches that are covered by algal wrack deposits (but see Dugan et al. 2003); thus, published studies reporting species richness, population abundance figures and zonation patterns of the upper beach macroinfauna, may well be seriously flawed.

\section{ACKNOWLEDGEMENTS}

The field work of this study was supported by FONDAP (Oceanografía \& Biología Marina, Programa Mayor no 3 ), CONICYT, Chile. R. de la Huz acknowledges a research grant given by Xunta de Galicia for travelling and living expenses in Chile. The assistance of $\mathrm{M}$. González and A.M. Ojeda during laboratory analyses is fully appreciated; also, the constructive review given by J. Dugan and two anonymous reviewers to an earlier version of this manuscript.

\section{LITERATURE CITED}

ANSELL AD (1983) The biology of the genus Donax. In: McLachlan A \& T Erasmus (eds) Sandy beaches as ecosystems: 607-635. Dr. W Junk Publishers, The Hague, The Netherlands.

AVELLANAL MH, E JARAMILLO, E NAYLOR, \& F KENNEDY (2000) Orientation of Phalerisida maculata Kulzer (Coleoptera, Tenebrionidae) in sandy beaches of the Chilean coast. Journal of Experimental Marine Biology and Ecology 247: 153-167.

BOWERS DE (1964) Natural history of two beach hoppers of the genus Orchestoidea (Crustacea: Amphipoda) with reference to their complemental distribution. Ecology 45: 678-696.

BROWN AC \& A McLACHLAN (1990) Ecology of sandy shores. Elsevier, Amsterdam, The Netherlands. 328 pp.

BROWN AC \& FJ ODENDAAL (1994) The biology of oniscid Isopoda of the genus Tylos. Advances in Marine Biology 30: 89-153.

COLOMBINI I, A ALOIA, M FALLACI, G PEZZOLI \& L CHELAZZI (2000) Temporal and spatial use of stranded wrack by the macrofauna of a tropical sandy beach. Marine Biology 136: 531-541.

CONTRERAS H, E JARAMILLO, C DUARTE \& A McLACHLAN (2003) Population abundances, growth and natural mortality of the crustacean macroinfauna at two sandy beach morphodynamic types in southern Chile. Revista Chilena de Historia Natural 76: 543-561.

CRAIG PC (1970) The behavior and distribution of the intertidal sand beetle, Thinopinus pictus (Coleoptera: Staphylinidae). Ecology 51: 10121017.

CRAIG PC (1973) Behaviour and distribution of sandbeach amphipod Orchestoidea corniculata. Marine Biology 23: 101-109.

CROKER RA \& EB HATFIELD (1980) Space partitioning and interactions in an intertidal sand-burrowing amphipod guild. Marine Biology 61: 79-88.

DAHL E (1952) Some aspects of the ecology and zonation of the fauna on sandy beaches. Oikos 4: 1-27.

DUARTE WE (1974) Orchestoidea tuberculata Nicolet, 1849 como organismo desintegrador de algas (Crustacea, Amphipoda, Talitridae). Noticiero Mensual del Museo Nacional de Historia Natural (Chile) 19: 3-9.

DUGAN JE, DM HUBBARD, DL MARTIN, JM ENGLE, DM RICHARDS, GE DAVIS, KD LAFFERTY \& AMBROSE (2000) Macrofauna communities of exposed sandy beaches on the southern California mainland and Channel Islands. In: Browne D (ed) Proceedings of the Fifth California Islands Symposium. Minerals Management Services: 339346. Camarillo, California, USA.

DUGAN JE, DM HUBBARD, MD McCRARY \& MO PIERSON (2003) The response of macrofauna communities and shorebirds to macrophyte wrack subsidies on exposed sandy beaches of southern California. Estuarine, Coastal and Shelf Science 58S: $25-40$ 
EFFORD IE (1966) Feeding in the sand crab Emerita analoga (Decapoda, Hippidae). Crustaceana 10: 167-182.

EMERY KO (1938) Rapid method of mechanical analysis of sands. Journal of Sedimentary Petrology 8: 105111

EMERY KO (1961) A simple method of measuring beach profiles. Limnology and Oceanography 6: 90-93.

GIBBS RJ, MD MATHEWS \& DA LINK (1971) The relationship between sphere size and settling velocity. Journal of Sedimentary Petrology 41: 7-18.

GÓMEZ J \& O DEFEO (1999) Life history of the sandhopper Pseudorchestia brasiliensis (Amphipoda) in sandy beaches with contrasting morphodynamics. Marine Ecology Progress Series 182: 209-220.

GRIFFITHS CL \& JME STENTON-DOZEY (1981) The fauna and rate of degradation of stranded kelp. Estuarine, Coastal and Shelf Science 12: 645-653.

GRIFFITHS CL, JME STENTON-DOZEY \& K KOOP (1983) Kelp wrack and the flow of energy through a sandy beach ecosystem. In: McLachlan A \& $\mathrm{T}$ Erasmus (eds) Sandy beaches as ecosystems: 547-559. Dr. W. Junk Publishers, The Hague, The Netherlands.

GUILER ER (1959a) The intertidal ecology of the Montemar area. Proceedings of the Royal Society of Tasmania 93: 165-183.

GUILER ER (1959b) Intertidal belt-forming species on the rocky coasts of northern Chile. Proceedings of the Royal Society of Tasmania 93: 35-58.

HAYES WB (1977) Factors affecting the distribution of Tylos punctatus (Isopoda, Oniscoidea) on beaches in southern California and northern Mexico. Pacific Science 31: 165-186.

HEDGPETH JW (1957) Sandy beaches. Geological Society of America. Memoir 67: 587-608.

HUNTER MD \& PW PRICE (1992) Playing chutes and ladders: heterogeneity and the relative roles of bottom-up and top-down forces in natural communities. Ecology 73: 724-732.

INGLIS G (1989) The colonization and degradation of stranded Macrocystis pyrifera (L.) C. Ag. by the macrofauna of a New Zealand sandy beach. Journal of Experimental Marine Biology and Ecology 125: 203-218.

JARAMILLO E (1987) Sandy beach macroinfauna from the Chilean coast: zonation patterns and zoogeography. Vie et Milieu 37: 165-174.

JARAMILLO E (1994) Patterns of species richness in sandy beaches of South America. South African Journal of Zoology 29: 227-234.

JARAMILLO (2001) The sand beach ecosystem of Chile. In: Seeliger U \& B Kjerfve (eds) Coastal marine ecosystems of Latin America: 219-227. SpringerVerlag, Berlin, Germany.

JARAMILLO E, W STOTZ, C BERTRÁN, J NAVARRO, C ROMÁN \& C VARELA (1980) Actividad locomotriz de'Orchestoidea tuberculata (Amphipoda, Talitridae) sobre la superficie de una playa arenosa del sur de Chile (Mehuín, Provincia de Valdivia). Studies on Neotropical Fauna and Environment 15: 9-33.

JARAMILLO E \& S FUENTEALBA (1993) Down-shore zonation of two cirolanid isopods during two spring-neap tidal cycles in a sandy beach of south central Chile. Revista Chilena de Historia Natural 66: 439-454

JARAMILLO E \& A McLACHLAN (1993) Community and population responses of the macroinfauna to physical factors over a range of exposed sandy beaches in south-central Chile. Estuarine, Coastal and Shelf Science 37: 615-624.

JARAMILLO E, A McLACHLAN \& PS COETZEE (1993) Intertidal zonation patterns of the macroinfauna over a range of exposed sandy beaches in southcentral Chile. Marine Ecology Progress Series 101: $105-118$

JARAMILLO E, MH AVELLANAL, M GONZÁLEZ \& F KENNEDY (2000) Locomotor activity of Phalerisida maculata Kulzer (Coleoptera, Tenebrionidae) on Chilean sandy beaches. Revista Chilena de Historia Natural 73: 67-77.

JARAMILLO E, H CONTRERAS, C DUARTE \& P QUIJÓN (2001) Relationships between community structure of the intertidal macroinfauna and sandy beach characteristics along the Chilean coast. Marine Ecology. Pubblicazioni della Stazione Zoologica di Napoli (Italy) 22: 323-342.

JARAMILLO E, H CONTRERAS, C DUARTE \& MH AVELLANAL (2003) Locomotor activity and zonation of upper shore arthropods in a sandy beach of north central Chile. Estuarine, Coastal and Shelf Science 58S: 177-197.

KENNEDY F, E NAYLOR \& E JARAMILLO (2000) Ontogenic differences in the circadian locomotor activity rhythm of the talitrid amphipod crustacean Orchestoidea tuberculata. Marine Biology 137: 511-517.

KENSLEY B (1974) Aspects of the biology and ecology of the genus Tylos Latreille. Annals of the South African Museum (South Africa) 65: 401-471.

KOOP K \& FJ FIELD (1980) The influence of food availability on population dynamics of a supralittoral isopod, Ligia dilatata (Brandt). Journal of Experimental Marine Biology and Ecology 48: $61-72$.

KOOP K \& CL GRIFFITHS (1982) The relative significance of bacteria, meio-and macrofauna on an exposed sandy beach. Marine Biology 66: 295-300.

KOOP K \& MI LUCAS (1983) Carbon flow and nutrient regeneration from the decomposition of macrophyte debris in a sandy beach microcosm. In: McLachlan A \& T Erasmus (eds) Sandy beaches as ecosystems: 249-262. Dr. W. Junk Publishers, The Hague, The Netherlands.

LEWIN J \& CT SCHAEFER (1983) The role of phytoplankton in surf ecosystems. In: McLachlan A \& T Erasmus (eds) Sandy beaches as ecosystems: 381-389. Dr. W. Junk Publishers, The Hague, The Netherlands.

MAcINTYRE RJ (1963) The supra-littoral fringe of New Zealand sand beaches. Transactions of the Royal Society of New Zealand 1: 89-103.

MARSDEN ID (1991a) Kelp-sandhopper interactions on a sand beach in New Zealand. I. Drift composition and distribution. Journal of Experimental Marine Biology and Ecology 152: 61-74.

MARSDEN ID (1991b) Kelp-sandhopper interactions on a sand beach in New Zealand. II. Population dynamics of Talorchestia quoyana (MilneEdwards). Journal of Experimental Marine Biology and Ecology 152: 75-90.

McARDLE S \& A McLACHLAN (1991) Dynamics of the swash zone and effluent line on sandy beaches. Marine Ecology Progress Series 76: 91-99.

McARDLE S \& A McLACHLAN (1992) Sand beach ecology: swash features relevant to the macrofauna. Journal of Coastal Research 8: 398-407.

McLACHLAN A (1983) Sandy beach ecology: a review. In: McLachlan A \& T Erasmus (eds) Sandy beaches 
as ecosystems: 321-380. Dr. W. Junk Publishers, The Hague, The Netherlands.

McLACHLAN A (1985) The biomass of macro and interstitial fauna on clean and wrack-covered beaches in western Australia. Estuarine, Coastal and Shelf Science 21: 587-599.

McLACHLAN A \& E JARAMILLO (1995) Zonation on sandy beaches. Oceanography and Marine Biology: Annual Review 33: 305-335.

MENGE BA, BA DALEY, J LUBCHENCO, E SANFORD, E DAHLHOFF, PM HALPIN, G HUDSON \& JL BURNAFORD (1999) Top-down and bottom-up regulation of New Zealand rocky intertidal communities. Ecological Monographs 69: 297-330.

MORENO CA, JP SUTHERLAND \& F JARA (1984) Man as a predator in the intertidal zone of southern Chile. Oikos 42: 155-160.

PENNING SC, TH CAREFOOT, M ZIMMER, JP DANKO \& A ZIEGLER (2000) Feeding preferences of supralittoral isopods and amphipods. Canadian Journal of Zoology 78: 1918-1929.

POLIS GA \& SD HURD (1995) Extraordinarily high spider densities on islands: flow of energy from marine to terrestrial food webs and the absence of predation. Proceedings of the National Academy of Sciences USA 92: 4382-4386.

POLIS GA \& SD HURD (1996) Linking marine and terrestrial food webs: allocthonous input from the ocean supports high secondary productivity on small island and coastal land communities. American Naturalist 147: 396-423.

RAFFAELLI D, I KARAKASSIS \& A GALLOWAY (1991) Zonation schemes on sandy shores: a multivariate approach. Journal of Experimental Marine Biology and Ecology 148: 241-253.

RENAUD PE, ME HAY \& TM SCHMITT (1990) Interactions of plant stress and herbivory: intraspecific variation in the susceptibility of a palatable versus an unpalatable seaweed to sea urchin grazing. Oecologia 82: 217-226.

RICHARDS LJ (1984) Field studies of foraging behaviour of an intertidal beetle. Ecological Entomology 9: 189-194.

SALVAT B (1964) Les conditions hydrodynamiques interstitielles des sédiment meubles intertidaux et le repartition verticale de la faune endogée. Compte Rendu Académie des Sciences (France) 259: 15761579.

SANTELICES B (1981) Perspectivas de investigación en estructura y dinámica de comunidades intermareales rocosas de Chile Central. I. Cinturones de macroalgas. Medio Ambiente (Chile) 5: 175-189.

SCHMALFUSS H \& K VERGARA (2000) The isopod genus Tylos (Oniscidea: Tylidae) in Chile, with bibliographies of all described species of the genus. Stuttgarter Beitrage zur Naturkunde 612: 1-42.

SEWARD-THOMPSON B \& J HAILS (1973) An appraisal on the computation of statistical parameters in grain size analysis. Sedimentology 11: 83-98.

SHORT AD \& LD WRIGHT (1983) Physical variability of sandy beaches. In: McLachlan A \& T Erasmus (eds) Sandy beaches as ecosystems: 133-144. Dr. W. Junk Publishers, The Hague, The Netherlands.

SOKAL RR \& FJ ROHLF (1995) Biometry: the principles and practice of statistics in biological research. WH Freeman, New York, New York, USA. 887 pp.

STENTON-DOZEY JME \& CL GRIFFITHS (1983) The fauna associated with kelp stranded on sandy beach. In: McLachlan A \& T Erasmus (eds) Sandy beaches as ecosystems: 557-568. Dr. W. Junk Publishers, The Hague, The Netherlands.

VÁSQUEZ JA, PA CAMUS \& FP OJEDA (1998) Diversidad, estructura y funcionamiento de ecosistemas costeros del norte de Chile. Revista Chilena de Historia Natural 71: 479-499. 
